\title{
The Effect of Liquidity Risks on the Relationship between Earnings and Stock Return on Jordanian Public Shareholding Industrial Companies
}

\author{
Mamoun SHAKATREH*
}

Received: February 13, 2020 Revised: March 1, 2020 Accepted: March 6, 2020.

\begin{abstract}
The objectives of this study are threefold: 1) to identify the concepts of earnings, stock return and liquidity risks on public shareholding industrial companies listed in the Amman Stock Exchange, 2) to investigate the relationship between earnings, stock return, strength and direction of this relationship, and 3) to find out the effect of liquidity risks at stock return and the effect of liquidity risks on the relationship between earnings and stock return on Jordanian public shareholding industrial companies. To achieve the objectives, an analytical descriptive approach was used. As the data on the public shareholding industrial companies listed in the Amman Stock Exchange were accredited by 52 companies for the period between 2014-2019, data validation tests and their suitability for analysis were considered. A linear regression test was used to test the study hypotheses on the statistical analysis program. The results show that there is a positive and significant correlation at significance level between the earnings and stock return. The results of the study also showed that there is a statistically significant negative effect at significance level of liquidity risk on stock return. In addition, it was demonstrated that liquidity risks have significant negative effects on the relationship between earnings and stock returns.
\end{abstract}

Keywords: Liquidity Risks, Earnings, Stock Return, Amman Stock Exchange

JEL Classification Code: C1, G2, L3

\section{Introduction}

The financial reports issued by companies are among the most important sources that provide decision makers with the necessary information that helps them evaluate the company's ability to continue and achieve positive results. Where investors are interested in financial reports because they provide useful information for making decisions in investing in them. Investors usually invest in companies that are believed to be profitable in the future, and the profit earned is called return, so shares are one of the most preferred types of securities for investors and are proof of ownership of the company's assets, so investors have the right to demand the company for profits through dividends. Profit from the rise in share prices, called share returns, is

${ }^{*}$ First Author and Corresponding Author. Professor, Finance Department, AL-Balqa Applied University, Jordan [Postal Address: As-Salt, Amman, 16665, Jordan] Tel: +962 795862727 ,

Email: drmamounshakatreh2020@gmail.com.

(c) Copyright: The Author(s)

This is an Open Access article distributed under the terms of the Creative Commons Attribution Non-Commercial License (http://Creativecommons.org/licenses/by-nc/4.0/) which permits unrestricted noncommercial use, distribution, and reproduction in any medium, provided the original work is properly cited. one of the most important issues for investors in the capital markets, where the rise and fall of stock prices is the main concern of investors, the more the share price increases, the more return that will be obtained and vice versa (Hanifah, 2016).

Babi (2015) believes that in the modern investment world, decision-making is perhaps the most important part of the investment procedures during which investors need to make the most effective decisions to increase their profits and wealth. Therefore, information is the most important factor in the decision-making process. In the stock market, all investment decisions are affected by information sources. Information is gathered from a variety of sources such as the media, financial analysts, company financial data and even stock market prices. Stock market theorists consider that accounting and financial reporting are the most important sources of information; therefore, one of the goals of accounting and financial reporting is to provide information to facilitate decision-making ( $\mathrm{Li} \& \mathrm{Wu}, 2014$ ).

Based on the above, this study identifies the relationship between earnings and stock return, and the impact of financial risks on this relationship on Jordanian public shareholding industrial companies (Raei \& Saeidi, 2010). 


\section{Literature Review}

Financial ratios are one of the oldest and most important financial analysis methods used in studying the financial position and the company's ability to pay its obligations. The importance of financial ratios stems from the fact that any number of different financial statement numbers, whether the statement of financial position or income statement, has no clear meaning in itself, except if it is compared to other numbers, then the ratio is a relationship between two or more items in the financial statements. Accordingly, liquidity risk arises from the difficulty or inability of the financial institution to fulfill its liquidity obligations in a timely manner and at a reasonable cost. Liquidity risk can also extend to financial institutions' inability to take advantage of employment opportunities and maintain growth expectations in their strategic plan (strategic risks) due to lack of liquidity or difficulty in obtaining affordable financing (Pimentel, 2015).

The stock return is defined as the real cash flow that the investor gets during a certain time period, which is the total gains or losses accrued from the investment during a specific time period. It represents the cash dividend distribution of the asset during that period as well as the change in the value of the asset from its investment value at the beginning of the period. It is a profit that the investor can make as a result of the acquisition and purchase of the stock, whether upon subscription or when it is traded after that (Hadosi, 2016).

On the other hand, Purnamasari, Herdjiono, and Setiawan (2012) believe that earnings of companies are one of their most important information. Earnings reflect management performance, regular profit estimation, investment risk assessment and solvency. Earnings contain useful information for forecasting stock prices. According to the effective market hypothesis, stock prices show an immediate reaction to the new information released by them. Finding a relationship between changes in accounting earnings and stock prices is very important because investors believe that share prices change according to the companies' ability to generate profits, and therefore investors begin to buy stocks when real returns exceed expected returns. The relationship between profits and dividends plays an important role in corporate stability.

Liquidity risk has received the attention of many researchers and the academic world, due to the significant increase in the size and diversity of risks, as well as the close correlation of these risks with value in profitability (Ogilo, 2015). Because of the importance of the issue of liquidity risk, earnings, and returns in investment (stock return), and their relationships and effects on each other, there have been many investigations in this field. Bin
Saadon (2019) examined the effect of liquidity on achieving profitability in Algerian commercial banks, which is evident by the search for mechanisms that contribute to achieving a balance between high profitability and meeting liquidity requirements. In light of the pursuit of its owner and shareholders to achieve the highest rates of profitability, its depositors aim to ensure that they get their money whenever they want it, with the privacy of its work based on the funds of others, whether lending or borrowing, and is characterized by the small size of its capital, which makes it vulnerable to great risks. The study concluded that liquidity has an important impact on profitability, as the availability of liquidity and its high rate, and the decrease in liquidity risk effectively lead to an increase in the profitability of banks, and an increase in the return on the stock in them.

Abdel and Bandar (2017) examined the impact of the liquidity risk indicators of the banking sector (the index of trading, the index of investments to deposits, the index of cash and investment to assets, loans to deposits) in the profitability indicators (rate of return on assets, rate of return on deposits, the right of ownership, the rate of return on available funds). The study concluded that the ratio of the effect of liquidity risk on profitability is high and significant in the research of banks sample.

Khalaf (2017) examined liquidity risk and its impact on the profitability of commercial banks, using the annual financial statements for the period of 2008-2013 of six Iraqi commercial banks. To test the hypotheses of the study, the percentages were extracted, and represent liquidity and profitability indicators. Simple regression analysis method and $\mathrm{T}$ test as tools for analysis were applied, through (SPSS 18) statistical program. Results showed the existence of a statistically significant relationship between the dependent and independent variables, namely standards of bank liquidity and profitability of the Iraqi sample banks. Some conclusions and recommendations are suggested in order to overcome the banking liquidity risks.

Al-Homaidi, Tabash, Al-Ahdal, and Farhan (2020) examine the determinants of the liquidity of the Indian companies listed experimentally. In order to calculate the persistence of stability, the researchers applied the influence models (combined, fixed and random) on a panel of Indian listed companies covering the time period from 2010 to 2016. This study consists of 2154 companies operating in the Hindi market. Liquidity (LQD) of Indian companies is measured with liquid assets to total assets, while bank size, capital adequacy, profitability, leverage and company life are used as internal determinants. Moreover, economic activity, inflation, exchange rate, and interest rate are the external factors discussed. The results reveal that the leverage, return on assets and the life of the 
company are the main internal factors affecting the liquidity of the listed Indian companies.

Al-Qadi and Qudah (2017) examined the effect of liquidity risk on the management of the performance of Jordanian commercial banks in the light of international standards. Based on an analysis of the data collected and test hypotheses, they found that there is no significant statistical impact on the level of liquidity risk management for the performance of the banking sector in light of international standards. Based on these results, this study recommends the necessity of complying with International Accounting Standards (IAS), Financial Reporting Standards (IFRS), and the securities issued by the Basel Committee on Banking Supervision, in accordance with regulatory requirements.

Babi (2015) investigated the effects of financial risks on the relationship between earnings per share and returns on shares in companies listed on the Tehran Stock Exchange. The study results indicated that there is a positive and important relationship between the earnings per share and the returns of the shares. In addition, the results demonstrated that credit and solvency risks have significant negative effects on the relationship between earnings per share and returns on stocks, but the effect of liquidity risk on this relationship has not been significant.

Allen, Larson, and Richard (2013) examined the relationship between due setbacks, profits, and stock returns. Their results showed that receivables consist of two distinct basic processes: one with a positive serial link and one with a negative serial link. They also found that the repercussions of accruals that characterize negative interconnected operations were essentially good entitlements that really anticipated fluctuations in working capital. Finally, they demonstrated that the accrual miscalculation was the least determining component of profit, while receivables related to the company's growth were less stable than cash flows.

Camba and Camba (2020) look at the dynamic relationship of domestic credit and stock market liquidity on the economic growth of the Philippines from 1995 to 2018, applying the autoregressive distributed lag (ARDL) bounds testing approach to co-integration, together with Granger causality test based on vector error correction model (VECM). The ARDL model indicated a long-run relationship of domestic credit and stock market liquidity on GDP growth. When the GDP per capita is the dependent variable there is weak co-integration. Also, the Johansen co-integration test confirmed the existence of long-run relationship of domestic credit and stock market liquidity both on GDP growth and GDP per capita.

Mashoka (2013) explored the relationship between earnings and stock returns on a sample of firms listed in the Amman Stock Exchange (ASE). Results show that the relationship between earnings and stock returns is stronger in the banking sector and weaker in the manufacturing sector. The results also show that as the percentage of accruals increase in earnings, the relationship becomes weaker. Furthermore, the results show that the investors understand the components of earnings suggesting that they understand the accounting practices relative to each sector.

Shabani, Aghaei, and Shabani (2013) investigated the relationship between earnings per share and earnings predicted for each share with stock price, and the relationship between earnings per share and dividends per share and also the deviation of predicted earnings of share from actual earnings or prediction error. The results of this study indicated that earnings per share and predicted earnings per share had a positive relationship with stock price, and there is a relationship between earnings per share and dividends per share, and most of accepted companies in the Stock Exchange anticipate their own earnings per share more than the actual value.

Vijayakumaran and Vijayakumaran (2019) examine the effects of growth opportunities, debt maturity, and liquidity risk on leverage, while benefiting from a wide range of listed Chinese companies. Research on the capital structure expanded its scope from the decision of the individual capital structure (choice of debt / equity) to the various debt characteristics of the corporate capital structure. The results of the study indicate that the economic effects of the liquidity risk effect are much lower for Chinese companies than those observed in the literature on US companies. These differences can be explained by the differences in the institutional environment in which companies operate.

Al-Araj (2013) studied banks operating in Jordan in applying the best banking practices in managing liquidity risk by identifying the factors proposed by the Basel Committee in managing liquidity risk and the extent of their application in banks operating in Jordan. The study's conclusions and recommendations point to the necessity for banks to adopt a general framework for managing liquidity risk, developing a strategy, policies and practices for managing liquidity risk, developing tools for measuring and monitoring liquidity risks, continuing to adhere to the disclosure requirements periodically, and inviting slavery bodies Able to develop its business in a way that ensures keeping abreast of the latest developments in the global banking market, and ensuring the implementation of stress tests of the financial system.

\section{Study Objectives}

This study aimed to:

-Identify the concepts of earnings, stock return and liquidity risks. 
-Identify the strength and direction of the relationship between earnings, stock return on Jordanian public shareholding industrial companies.

-Find out the effect of liquidity risks at stock return on Jordanian public shareholding industrial companies.

-Find out the effect of liquidity risks on the relationship between earnings and stock return on Jordanian public shareholding industrial companies.

\section{Hypotheses}

The purpose of this study was to investigate the effects of liquidity risk on the relationship between earnings per share and stock returns on Jordanian Public Shareholding Industrial Companies. Therefore, the following research hypotheses are formulated:

H1: There is no statistically significant relationship at the level $(\alpha \leq 0.05)$ between Earnings and Stock Return on Jordanian Public Shareholding Industrial Companies.

H2: There is no statistically significant impact at the level $(\alpha \leq 0.05)$ of liquidity risk at the Stock Return on Jordanian Public Shareholding Industrial Companies

H3: There is no statistically significant impact at the level $(\alpha \leq 0.05)$ of liquidity risk on the relationship between Earnings and Stock Return on Jordanian Public Shareholding Industrial Companies.

\section{Data and Methodology}

The study followed the descriptive analytical approach in describing the effect of liquidity risks in the relationship between earnings and stock return on Jordanian public shareholding industrial companies. This method aims to describe specific phenomena or events and collect their data as they are in reality, then the research data was analyzed statistically to test the hypotheses.

\subsection{Population and Study Sample}

The study population consists of all Jordanian public shareholding industrial companies listed on the Amman Stock Exchange (www.ase.jo), which numbered 52 until the end of the year (2019).

The study community companies were chosen according to the following criteria:

-The company's shares are traded in the Amman Stock Exchange during the study period.
-The company must have all the data necessary to calculate study variables.

-The company has not merged or stopped trading during the study period.

\subsection{Measurement of Study Variables}

This study aimed to analyze the impact of liquidity risks on the relationship between earnings and stock return on Jordanian public shareholding industrial companies, and thus the study variables consist of the following:

\subsubsection{Independent Variable: Earning}

This variable is calculated through dividing common shareholders' net income by the weighted average common shares outstanding. The result of the ratio showed the amount of earnings per share, and higher earnings per share ratio indicated higher company efficiency measured by the following formula:

$$
\text { Earning }=(\text { Net Income } / \text { Value traded }) * 100
$$

\subsubsection{Dependent Variable: Stock Returns}

The study relies on measuring the dependent variable represented by the returns of shares, on the financial data related to the Jordanian public shareholding industrial companies, issued in the form of annual financial reports represented in the historical closing prices and measured by the following formula:

$$
\text { Stock return }=(\mathrm{Pt}-\mathrm{Pt}-1) / \mathrm{Pt}-1 * 100 \%
$$

Where:

$\mathrm{Pt}=$ closing price for the current year

Pt-1 = closing price for the past year

\subsubsection{Moderating Variable: Liquidity Risk}

Liquidity risk as the moderating variable of the study was calculated by the ratio of net debt to total assets, with the following formula:

$$
\text { Liquidity risk }=\text { ratio of net deb/ total assets }
$$

\section{Results}

Correlation coefficients between independent variables were calculated to test the presence of the Multicollinearity phenomenon, by calculating the Variance inflation factor (VIF), in addition to testing the presence of multiple linear correlation through the Darbun-Watson (DW) test, and Time Series Stationary was tested. 


\subsection{Multicollinearity Test}

The assumption of the independence of independent variables and the presence of a linear relationship in the General Linear Model (GLM) is the basis for the validity of the application of this model, and the model cannot be considered appropriate for the process of estimating parameters unless this hypothesis is fulfilled (Guajarati, 2004). This phenomenon indicates the existence of an almost perfect linear correlation between two or more variables that amplifies the value of the coefficient of determination (R2) and makes it greater than its actual value. For this, the values of correlation coefficients between the variables of the study model were calculated, and the results are as follows:

Table 1 shows that the correlation coefficient between the dependent variable (Stock Returns) and the independent variable (Earning) is a value of (0.568), which is a significant value at a significance level less than (0.05). This indicates the existence of the linear correlation between dependent and independent variables. It was also found that the value of the correlation coefficient between the independent variable and the moderating variable (0.669) indicates that there is no phenomenon of multiple linear correlation between the two variables, as it was less than $(0.80)$, and this is considered an indication that the sample is free from the problem of multicollinearity (Guajarati, 2004).

Table 1: Correlation matrix for independent variable

\begin{tabular}{|c|c|c|c|c|}
\hline \multicolumn{2}{|c|}{ Variable } & $\begin{array}{c}\text { Stock } \\
\text { returns }\end{array}$ & Earning & $\begin{array}{c}\text { Liquidity } \\
\text { risk }\end{array}$ \\
\hline \multirow{2}{*}{$\begin{array}{c}\text { Stock } \\
\text { returns }\end{array}$} & $\mathrm{C}$-Value & 1.0 & & \\
\cline { 2 - 5 } & $\mathrm{Sig}$ & - & & \\
\hline \multirow{2}{*}{ Earning } & $\mathrm{C}-$ Value & 0.564 & 1.0 & \\
\cline { 2 - 5 } & $\mathrm{Sig}$ & $0.000^{*}$ & - & \\
\hline \multirow{2}{*}{$\begin{array}{c}\text { Liquidity } \\
\text { risk }\end{array}$} & $\mathrm{C}-$ Value & 0.708 & 0.669 & 1.0 \\
\cline { 2 - 5 } & $\mathrm{Sig}$ & $0.000^{*}$ & $0.000^{*}$ & - \\
\hline
\end{tabular}

\subsection{Autocorrelation}

One of the regression conditions is the absence of data from the problem of autocorrelation, which is defined as the existence of a correlation between the limits of random error in the regression model, which results in a bias in the value of estimated parameters, thus weakening the model's ability to predict. This is confirmed by the Durbin-Watson Test, which is the most commonly used; the value of this test ranges between ( 0 and 4$)$. The existence of the autocorrelation phenomenon is rejected if the value of (DW) equals or approaches 2 (Gujarati, 2004). Table 2 shows the results of the Durbin-Watson Test for the study hypotheses.

Table 2: Autocorrelation test

\begin{tabular}{|c|c|c|}
\hline Hypothesis & D-W calculated Value & Result \\
\hline H01 & 1.975 & No autocorrelation \\
\hline H02 & 2.088 & No autocorrelation \\
\hline H03 & 2.080 & No autocorrelation \\
\hline
\end{tabular}

Note that the $\mathrm{D}-\mathrm{W}$ values for the variables in the entire hypothesis are approaching the number 2, which indicates that the data are free from the problem of autocorrelation, that is, there is no correlation between the limits of random error in the regression model.

\subsection{Stationary Test}

The stability of time series indicates the stability of each mean and the variance of the series values over time, and that the Covariance variation between two time periods depends only on the time gap, not on the real time in which the Covariance is measured. The Unit Root test is applied in order to make sure whether the study variables are stable or not. An Augmented Dickey-Fuller (ADF) test has, thus, been performed to test the hypothesis of whether the variables contain the unit root, and if these variables contain the unit root, differences should be taken to make them static, as many of the Time series may be non-static, but give higher values for R2, F, and T. This leads to misinterpretation and misleading results, therefore unit root test must be performed to check how time series are still (Greene, 2003). The decision rule for the ADF test is in the presence of the unit root (time series instability) if the level of significance of the calculated test value is greater than 0.05; the results follow.

Table 3 indicates the results of the data stationary test related to the study variables, using the (Augmented Dickey-Fuller (ADF) test. From this, it becomes clear that all-time series data used in the study are stable with the passage of time because all probability values (P-Value) for variables are not exceeding the $5 \%$ level, therefore we reject the hypothesis of the existence of the unit root, so the time series is stable.

Table 3: Unit root test

\begin{tabular}{|c|c|c|c|}
\hline Variable & $\begin{array}{c}\text { Calculated } \\
\text { Value }\end{array}$ & P-Value & Result \\
\hline Stock returns & -16.728 & 0.000 & Stationary \\
\hline Earning & -10.521 & 0.000 & Stationary \\
\hline Liquidity risk & -7.646 & 0.000 & Stationary \\
\hline
\end{tabular}




\subsection{Hypothesis Testing}

\subsubsection{First Hypothesis}

H1: There is no statistically significant relationship at the level $(\alpha \leq 0.05)$ between Earnings and Stock Return on Jordanian Public Shareholding Industrial Companies. Simple linear regression analysis was used to test this hypothesis, and the results were as follows:

Table 4 indicates that the value $(r=0.564)$ means that there is a positive correlation value of $(56.4 \%)$ which is considered to be average between (Earnings) and (Stock Return) on Jordanian Public Shareholding Industrial Companies. The coefficient of determination value $\left(\mathrm{r}^{2}=\right.$ $0.319)$ means that the variation in (Earnings) explained $(31.9 \%)$ of the variance in (Stock Return), as the analysis of variance shows that the value of (f) has reached (60.79) when Confidence level $(\mathrm{sig}=0.000)$. This confirms the significance of regression at $(\alpha \leq 0.05)$ level, and at one degree of freedom. From the coefficient table, the value of $(0.564=\beta)$ means that the increase in one unit in the (Earnings) variable on Jordanian Public Shareholding Industrial Companies leads to an increase of $(56.4 \%)$ in (Stock Return), and the value of $(t=7.79)$ at a confidence level $(\mathrm{sig}=0.000)$ confirms the coefficient significance at $(\alpha \leq 0.05)$ level.

Based on the above analysis, we reject the first null hypothesis and accept the alternative hypothesis: there is a statistically significant relationship at the level $(\alpha \leq 0.05)$ between Earnings and Stock Return on Jordanian Public Shareholding Industrial Companies.

Table 4: Simple regression analysis, the effect of Earnings on Stock Return

\begin{tabular}{|c|c|c|c|c|c|c|c|c|c|c|}
\hline Dependent Variable & \multicolumn{2}{|c|}{ Model summery } & \multicolumn{3}{|c|}{ ANOVA } & \multicolumn{4}{c|}{ Coefficient } \\
\hline \multirow{2}{*}{ Stock Return } & $\mathrm{r}$ & $\mathrm{r}^{2}$ & $\mathrm{f}$ & $\mathrm{DF}$ & Sig F* & \multirow{2}{*}{ Earnings } & $\beta$ & Std. Error & $\mathrm{t}$ & \multicolumn{1}{|c|}{ Sig F* } \\
\cline { 2 - 14 } & 0.564 & 0.319 & 60.79 & 1 & 0.000 & & 0.564 & 0.067 & 7.79 & 0.000 \\
\hline
\end{tabular}

\subsubsection{Second Hypothesis}

H2: There is no statistically significant impact at the level $(\alpha \leq 0.05)$ of liquidity risk on the Stock Return on Jordanian Public Shareholding Industrial Companies. Simple linear regression analysis was used to test this hypothesis, and the results were as follows:

Table 5 indicates that the value of $(\mathrm{r}=-0.708)$ means that there is a negative correlation value of $(70.8 \%)$ which is considered to be high between (liquidity risk) and (Stock Return) on Jordanian Public Shareholding Industrial Companies. The coefficient of determination value $(\mathrm{r} 2=$ $0.501)$ means that the variation in (liquidity risk) has explained (50.1\%) of the variance in (Stock Return), as the analysis of variance shows that the value of (f) has reached (133.61) when Confidence level $(\mathrm{sig}=0.000)$. This confirms the significance of regression at $(\alpha \leq 0.05)$ level, and at one degree of freedom. From the coefficient table, the value of $(-0.708=\beta)$ means that the increase in one unit in the (liquidity risk) variable on Jordanian Public Shareholding Industrial Companies leads to an decrease of $(70.8 \%)$ in (Stock Return), and the value of $(t=11.56)$ at a confidence level $(\mathrm{sig}=0.000)$. This confirms the coefficient significance at $(\alpha \leq 0.05)$ level.

Based on the above analysis, we reject the second null hypothesis and accept the alternative hypothesis: there is a statistically significant impact at the level $(\alpha \leq 0.05)$ of liquidity risk on the Stock Return on Jordanian Public Shareholding Industrial Companies.

Table 5: Simple regression analysis, the effect of liquidity risk on Stock Return

\begin{tabular}{|c|c|c|c|c|c|c|c|c|c|c|}
\hline Dependent Variable & \multicolumn{2}{|c|}{ Model summery } & \multicolumn{3}{|c|}{ ANOVA } & \multicolumn{4}{|c|}{ Coefficient } \\
\hline \multirow{2}{*}{ Stock Return } & $\mathrm{r}$ & $\mathrm{r}^{2}$ & $\mathrm{f}$ & $\mathrm{DF}$ & $\mathrm{Sig} \mathrm{F}$ & \multirow{2}{*}{ liquidity risk } & $\beta$ & Std. Error & $\mathrm{t}$ & Sig F* \\
\cline { 2 - 13 } & -0.708 & 0.501 & 133.61 & 1 & 0.000 & & -0.708 & 0.062 & 11.56 & 0.000 \\
\hline
\end{tabular}

\subsubsection{Third Hypothesis}

H3: There is no statistically significant impact at the level $(\alpha \leq 0.05)$ of liquidity risk on the relationship between Earnings and Stock Return on Jordanian Public Shareholding Industrial Companies. To test this hypothesis, a Hierarchical Regression analysis was used. The results were as follows:
Table 6 shows the results of a hierarchical regression analysis based on two models, as the results of the first model shown on the first step reflected the presence of a statistically significant effect of (Earnings) variable in (Stock Return), where the value of $(\mathrm{F}=60.79)$ and the level of significance ( $\operatorname{sig} \mathrm{F}=0.000$ ) which is less than $(0.05)$ as was the value of the determination coefficient $\left(\mathrm{R}^{2}=0.319\right)$. This indicates that (Earnings) explains $(31.9 \%)$ of the 
variance in (Stock Return) In the second step, a liquidity risk variable was entered in the regression model where the value of the determination coefficient $\left(\mathrm{R}^{2}\right)$ decreased by $(17.2 \%)$ and this ratio is statistically significant where the value of $(\Delta F=17.20)$ and the level of significance $(\operatorname{sig} \Delta F$ $=0.000)$ is less than $(0.05)$. Also, the value of $(\beta=0.383)$ at (liquidity risk) and value $(\mathrm{t}=5.304)$ with the level of significance $(\mathrm{sig} .=0.000)$. This confirms the significant effect of (liquidity risk) on reducing the effect of (Earnings) on (Stock Return), where The explanation of the variation ratio decreased by $(17.2 \%)$, from $(31.9 \%)$ to $(147 \%)$.

Based on the above analysis, we reject the third null hypothesis and accept the alternative hypothesis: there is a statistically significant impact at the level $(\alpha \leq 0.05)$ of liquidity risk on the relationship between Earnings and Stock Return on Jordanian Public Shareholding Industrial Companies.

Table 6: Hierarchical regression analysis, the effect of liquidity risk on relationship between Earnings and Stock Return

\begin{tabular}{|c|c|c|c|c|c|c|c|}
\hline \multirow{4}{*}{$\begin{array}{c}\text { Dependent } \\
\text { Variables }\end{array}$} & \multirow{2}{*}{$\begin{array}{c}\text { Independent } \\
\text { Variable }\end{array}$} & \multicolumn{3}{|c|}{ First step } & \multicolumn{3}{|c|}{ Next step } \\
\cline { 2 - 7 } & Earning & 0.564 & 7.79 & 0.000 & 0.459 & 6.88 & 0.000 \\
\cline { 2 - 7 } & $\begin{array}{c}\text { liquidity } \\
\text { risk }\end{array}$ & \multicolumn{2}{|c|}{} & 0.383 & 5.304 & 0.000 \\
\hline \multirow{4}{*}{$\begin{array}{c}\text { Stock } \\
\text { Return }\end{array}$} & $\mathrm{R}^{2}$ & \multicolumn{2}{|c|}{0.319} & \multicolumn{3}{|c|}{0.147} \\
\cline { 2 - 7 } & $\mathrm{R}^{2} \Delta$ & \multicolumn{2}{|c|}{0.319} & \multicolumn{3}{|c|}{0.142} \\
\cline { 2 - 7 } & $\mathrm{F} \Delta$ & \multicolumn{2}{|c|}{60.79} & \multicolumn{3}{|c|}{17.20} \\
\cline { 2 - 7 } & $\mathrm{F}$ & $\Delta \mathrm{sig}$ & \multicolumn{2}{|c|}{0.000} & \multicolumn{3}{|c|}{0.000} \\
\hline
\end{tabular}

\section{Discussion and Conclusion}

This study was conducted for the purpose of evaluating the effects of liquidity risks on the relationship between earnings and stock returns. The results show that there is a positive and significant correlation between the earnings and stock return. They also show that there is a statistically significant negative effect of liquidity risk on stock return. In addition, it was demonstrated that liquidity risks have significant negative effects on the relationship between earnings and stock returns. Therefore, according to these results, companies accepted on the stock exchange are said to pay special attention to these risk factors during initial valuations of a stock purchase. This result can be explained by the fact that the higher degree of liquidity risk, the higher possibility of loss and failure in companies, as well as the failure of investors to invest in companies' shares, that leads to lower trading, and thus lower earnings, which in turn leads to a decrease in stock return.
More research in this field strongly recommended. Future research should investigate the effects of market risk, commercial risk, growth, capital structure, and so forth, on the relationship between earnings and returns. In addition, this study investigated the companies accepted on the stock exchanges. Future studies can look into banks, investment institutions and companies, and other organizations. In other words, applying the research design to other companies and profession is recommended for future research, and to increase the generalization of the present study, more data collection from various locations is needed.

\section{References}

Al-Araj, A. (2013). Liquidity risk management in banks operating in Jordan The extent to which best practices are applied in managing liquidity risk in banks operating in Jordan. Journal of Baghdad College for University Economic Sciences, 25, 103-122

Abdel, A., \& Bandar, N. (2017). Liquidity risk and its impact on the profitability of Islamic banks: Applied research in a sample of Iraqi Islamic banks for the period (2011-2015). Tikrit Journal of Administration \& Economic Sciences, 40(4), 1-25.

Al-Homaidi, E., Tabash, M. I., Al-Ahdal, W. M., \& Farhan, N. HS. (2020). The Liquidity of Indian Firms: Empirical Evidence of 2154 Firms. Journal of Asian Finance, Economics and Business, 7(1), 19-27. https://doi.org/10.13106/jafeb.2020.vol7.no1.19.

Allen, E., Larson, C., \& Richard, G., S. (2013). Accrual reversals, earnings and stock returns. Journal of Accounting Economics, 56(1), 113-129

Al-Qadi, N., \& Qudah, L., (2017). Managing the liquidity risk and its impact on the performance of the commercial banking sector in light of international standards: an applied study on Jordanian commercial banks. Studies in Economics Trade and Finance Journal, 6(1), 107-154.

Babi, M. (2015). The effects of financial risks on the relationship between earnings and stock returns. International Journal of Organizational Leadership, 4(2015) 154-169.

Bin Saadon, S. (2019). The effect of liquidity on profitability in commercial banks: A comparative study of a number of public and private Algerian banks for the period (2013-2017) (Master thesis). College of Economic and Commercial Sciences, 8 May University, Algeria.

Camba, A. C., \& Camba, A.L. (2020). The Dynamic Relationship of Domestic Credit and Stock Market Liquidity on the Economic Growth of the Philippines. Journal of Asian Finance, Economics and Business, 7(1), 37-46. https://doi.org/10.13106/jafeb.2020.vol7.no1.37

Greene, W. H. (2003). Econometric Analysis (5th ed.). Upper Saddle River, NJ: Prentice Hall.

Guajarati, D. N. (2004). Basic Econometrics (4th ed.). New York, NY: McGraw Hill.

Hadosi, A. (2016). The effect of the size of the institutions on the stock returns on the Amman Stock Exchange (2012 -2014). Journal of Administrative and Economic Sciences, 12(2), 135122. 
Hanifah, U., \& Khafid, M. (2016). The Analysis of Earnings Persistence Roles in Mediating the Effect of Operating Cash Flow and Debt Level on Stock Return. Accounting Analysis Journal, 5(4), 290-298.

Khalaf, M., (2017). Liquidity risk and its impact on the profitability of commercial banks: An applied study on a sample of commercial banks in Iraq. Journal of Baghdad College for University Economic Sciences, 52, 401-414.

Li, M. Y., \& Wu, J. S. (2014). Analysts' forecast dispersion and stock returns: A quintile regression approach. Journal of Behavioral Finance, 15(3), 175-183.

Mashoka, T. Z. (2013). The Relationship between Earnings and Stock Returns on the Market and Sector Levels. Dirasat, Administrative Sciences, 40(2), 555-564.

Ogilo, F. (2015). Determinants of Liquidity Risk of Commercial bank in Kenya. The International Journal of Business \& Management, 9(3). DOI:10.5539/ijef.v9n3p256.

Pimentel, C. (2015). Unexpected Earnings, Stock Returns, and Risk in the Brazilian Capital Market, USP. Sao Paulo, 26(69).
DOI: $10.1590 / 1808-057 \times 201501270$.

Purnamasari, K., Herdjiono, I., \& Setiawan, E. (2012). Financial risks, growth, earnings and stock returns relationship: The case of Indonesia. International Review of Business Research Papers, 8(7), 79-93.

Raei, R., \& Saeidi, A. (2010). The principles of financial engineering and risk management (5th ed.). Tehran, Iran: SAMT.

Shabani, V., Aghaei, S., \& Shabani, V. (2013). Investigating the Relationship between Earnings and Stock Prices in Companies Accepted in the Stock Exchange: A Case Study in Iran (20002010). European Online Journal of Natural and Social Sciences, 2(3), 3102-3116.

Vijayakumaran, S., \& Vijayakumaran, R. (2019). Debt Maturity and the Effects of Growth Opportunities and Liquidity Risk on Leverage: Evidence from Chinese Listed Companies. Journal of Asian Finance, Economics and Business, 6(3), 27-40. https://doi.org/10.13106/jafeb.2019.vol6.no3.27 